\title{
Rancang Bangun Generator Kedap Air Untuk PLTPH Pada Aliran Sungai
}

\author{
Andreas Pangkung ${ }^{*}$, Marhatang ${ }^{2}$ A. Muh. Raihan ${ }^{3}$, Aulia Ramadhana ${ }^{4}$ \\ 1,2,3,4 Jurusan Teknik Mesin, Politeknik Negeri Ujung Pandang, Makassar 90245, Indonesia \\ *andareaspangkung@gmail.com
}

\begin{abstract}
Rivers that have potential energy can be used as power plants by using a waterproof generator as a conversion of mechanical energy into electrical energy. The purpose of this design is to utilize the river flow as a power generator in rural areas so that the economy in the village will increase. The design is carried out by surveying the field and calculating the water velocity, then designing a waterproof generator. In testing a waterproof generator is done by measuring the voltage of the one-phase and three-phase test circuits, as well as the generator rotation. The test results of a waterproof generator with a river flow rate of $0.58 \mathrm{~m} / \mathrm{s}$ produce a voltage of 11 volts at $108 \mathrm{rpm}$ in a single phase system and have an insulation resistance of $50 \mathrm{~K} \Omega$. Then in a three-phase system with a Y connection, the line to line voltage is 28 volts, the line to neutral voltage is 17 volts with a rotation of $108 \mathrm{rpm}$, while the $\Delta$ connection, the line to line voltage is 12 volts with the same rotation as the Y connection.
\end{abstract}

Keywords: generator, waterproof, river, electrical energy

\begin{abstract}
Abstrak: Sungai yang memiliki energi potensial dapat dimanfaatkan sebagai pembangkit listrik dengan menggunakan generator kedap air sebagai konversi energi mekanik menjadi energi listrik. Tujuan dari rancang bangun ini untuk memanfaatkan aliran sungai sebagai pembangkit listrik di pedesaan agar meningkatnya perekonomian di desa tersebut. Perancangan dilakukan dengan survei lapangan dan menghitung kecepatan air, kemudian merancang desain generator kedap air. Pada pengujian generator kedap air dilakukan dengan mengukur tegangan rangkaian pengujian satu fasa dan tiga fasa, serta putaran generator. Hasil pengujian generator kedap air dengan kecepatan aliran sungai sebesar $0,58 \mathrm{~m} / \mathrm{s}$ menghasilkan tegangan 11 Volt pada putaran $108 \mathrm{rpm}$ pada sistem satu fasa dan memiliki tahanan isolasi sebesar $50 \mathrm{~K} \Omega$. Kemudian pada sistem tiga fasa dengan hubungan Y, tegangan line to line sebesar 28 Volt, tegangan line to netral sebesar 17 Volt dengan putaran $108 \mathrm{rpm}$, sedangkan hubungan $\Delta$, tegangan line to line sebesar 12 Volt dengan putaran yang sama dengan hubungan $Y$.
\end{abstract}

Kata kunci : generator, kedap air, sungai, energi listrik

\section{PENDAhuluan}

Pembangkit listrik terbarukan merupakan pilihan terbaik untuk memenuhi kebutuhan energi listrik dunia. Mengingat mahal dan langkanya energi minyak bumi yang selama ini selalu menjadi pilihan utama pada sistem pembangkitan energi listrik, untuk mengatasi hal tersebut maka dibutuhkan pembangkit listrik yang memanfaatkan energi terbarukan, salah satunya yaitu Pembakit Listrik Tenaga Piko-hidro [1].

Pada umumnya pembangkit listrik menggunakan generator sebagai penghasil energi listrik. Adapun jenis generator berdasarkan putarannya ada dua yaitu, high speed induction dan low speed [2-3]. Generator yang tersedia dipasaran biasanya berjenis high speed induction dimana generator jenis ini membutuhkan putaran tinggi dan juga membutuhkan energi listrik awal untuk membuat medan magnetnya. Pada perancangan generator untuk skala piko-hidro dibutuhkan generator yang berjenis low speed karena generator jenis ini bisa menghasilkan energi listrik dengan putaran rendah dan tanpa energi awal [3-6].

Penelitian tugas akhir ini bertujuan untuk merancang generator kedap air dengan memanfaatkan aliran sungai. Generator yang dimaksud yaitu generator fluks aksial dimana magnet sebagai rotor dan 
kumparan sebagai stator. Pada bagian kumparan ini diisolasi menggunkan fiber agar kedap air. Dengan menggunakan generator yang kedap air ini maka sangat berguna dalam pembangkitan listrik tenaga kecil dengan daya yang dapat melayani sebuah rumah di pedesaan yang tidak dialiri listrik.

\section{A. Energi Air}

Air merupakan salah satu energi terbarukan dan ramah lingkungan. Air yang mengalir dari hulu ke hilir mempunyai energi potensial yang dapat dimanfaatkan untuk memutar turbin pada pembangkit listrik tenaga air [7-8].

Provinsi Sulawesi Selatan menyimpan potensi besar sumber energi terbarukan, diantaranya 19 titik potensi pembangkit listrik tenaga air 2.946,8 MW, 18 lokasi potensi pembangkit mini hidro 70,2 MW dan 181 lokasi pembangkit listrik tenaga mikro hidro 7,66 MW. Potensi PLTA yang mencapai 2.946,8 MW, telah termanfaatkan sebesar $518 \mathrm{MW}$. Sementara untuk mini hidro telah termanfaatkan 10,6 MW dari potensi sebesar 70,2 MW, dan telah terpasang 63 unit PLTMH kapasitas $1.897 \mathrm{~kW}$ dari potensi sebesar 7.662,9 MW [9].

\section{B. Pembangkit Listrik Tenaga Air}

Pembangkit Listrik Tenaga Air adalah pembangkit listrik yang memanfaatkan energi air sebagai penggerak mula turbin untuk menghasilkan energi listrik. Air mengalir melalui pipa pengarah dimana air akan menabrak sudu-sudu yang menyebabkan turbin berputar. Energi mekanik yang dihasilkan turbin air berasal dari energi kinetik air [7].

\section{Komponen Piko-hidro}

\section{Turbin Air}

Turbin air adalah sebuah mesin yang mengubah energi dari aliran fluida menjadi energi mekanik poros. Mesin tersebut mengubah energi yang terkandung dalam air (energi potensial air) menjadi energi mekanik yang berupa putaran poros. Perubahan energi tersebut terjadi pada sudu-sudu turbin karena adannya aliran air secara terus menerus yang menyebabkan terjadinya pertukaran energi antara air dan sudu-sudu dalam bentuk pertukaran momentum [7-8].

Adapun pada pembangkit listrik tenaga piko-hidro ini menggunakan propeller sebagai turbin. Turbin jenis ini berfungsi untuk mengubah energi potensial menjadi energi mekanik. Kecepatan aliran air yang mendorong baling-baling menyebabkan turbin berputar. Berdasarkan penelitian terdahulu, jika kecepatan rata-rata air sebesar $2 \mathrm{~m} / \mathrm{s}$ maka kecepatan putar propeller sebesar $240 \mathrm{rpm}$ [1].

Turbin air kebanyakan seperti kincir angin, fungsi tenaga angin untuk memutar baling-baling diganti dengan tenaga air untuk memutar turbin. Perputaran turbin ini dihubungkan ke generator menggunakan sistem transmisi. Energi mekanik diubah menjadi energi listrik [8].

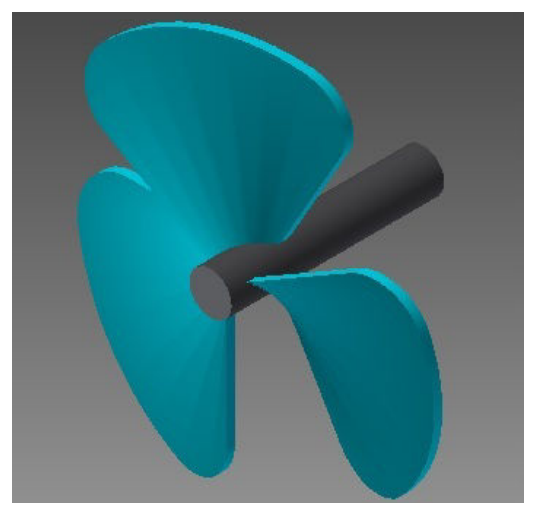

Gambar 1. Turbin air 
97 Andreas Pangkung, Marhatang, A. Muh. Raihan, Aulia Ramadhana. Rancang Bangun Generator Kedap Air Untuk PLTPH Pada Aliran Sungai

\section{Generator}

Secara umum konstruksi generator ac ini terdiri dari dua bagian utama [2-3], yaitu stator dan rotor.

a. Stator merupakan bagian yang diam yang mengeluarkan tegangan bolak-balik, stator berbentuk bulat dan terbuat dari besi dan disekelilingnya terdapat kumparan. Jumlah kumparan pada stator akan sangat menentukan besarnya tegangan yang dibangkitkan oleh sebuah generator. Stator pada umumnya terdiri dari 4 komponen utama yaitu rangka stator, inti stator, alur stator dan kumparan stator.

b. Rotor merupakan bagian yang berputar yang didalamnya terdapat magnet baik permanen maupun magnet buatan. Rotor yang menggunkan magnet permanen pada umumnya terdiri dari dua komponen utama yaitu magnet permanen dan poros rotor. Magnet permanen dipasang pada rotor yang merupakan bagian generator yang berputar sehingga rotor dapat menghasilkan medan magnet, sedangkan poros rotor merupakan suatu benda yang terbuat dari besi berbentuk silinder yang merupakan tempat meletakkan rotor, sehingga rotor terhubung dengan penggerak mula.

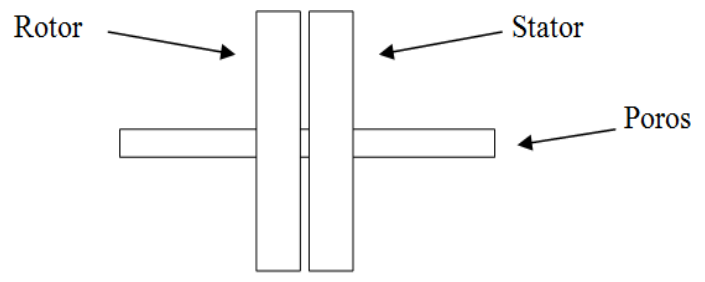

Gambar 2. Susunan stator dan rotor

Adapun persamaan untuk gaya gerak listrik yaitu [2-3]:

$\mathrm{E}_{\text {eff }}=\mathrm{C} . \mathrm{N} \cdot \Phi_{\mathrm{m}}$

Dengan:

$\mathrm{E}_{\text {eff }} \quad=$ ggl induksi maksimum (Volt)

$\mathrm{C}=$ konstanta

$\mathrm{N} \quad=$ putaran rotor $(\mathrm{rpm})$

$\Phi_{\mathrm{m}} \quad=$ fluks magnet $(\mathrm{Wb})$

\section{Prinsip Kerja Piko-hidro}

Pembangkitan listrik dengan tenaga air merupakan pembangkitan yang paling ekonomis. Sehingga potensi tenaga air perlu dimanfaatkan. Seperti pembangkit listrik mikro-hidro atau pikohidro dengan menggunakan turbin air sebagai penggeraknya [6].

Pertama, aliran air diarahkan ke turbin air sedemikian rupa sehingga turbin air dapat berputar. Putaran dapat terjadi karena aliran air menabrak sudu-sudu turbin sehingga energi mekanis dari air diubah untuk menggerakkan turbin. Seiring perputaran kincir air maka poros kincir air pun ikut berputar. Putaran dari poros kincir air tidak dapat secara langsung digunakan untuk memutar generator karena putaran poros harus disesuaikan dengan spesifikasi generator. Karena itulah diperlukan adanya transmisi mekanik, tidak lain untuk menyesuaikan putaran seperti apa yang diinginkan (sesuai dengan spesifikasi generator) [6].

Adapun rancangan piko-hidro tipe propeller yang didesain bekerja dengan memanfaatkan aliran sungai yang memiliki kedalaman berkisar $70 \mathrm{~cm}$ hingga $1,5 \mathrm{~m}$. Air yang mengalir disalurkan dengan 
kecepatan tertentu menuju turbin air. Air tersebut akan menabrak turbin dimana turbin akan menerima energi potensial tersebut dan mengubahnya menjadi energi mekanik berupa putaran pada poros turbin

\section{E. Fiberglass}

Fiberglass merupakan bahan paduan atau campuran beberapa bahan kimia (bahan komposit) yang bereaksi dan mengeras dalam waktu tertentu. Bahan ini mempunyai beberapa keuntungan dibandingkan bahan logam, diantaranya lebih ringan, lebih mudah dibentuk tidak berkarat, lebih murah dan mudah didapatkan [10-11].

Mulai akhir tahun 1930-an, fiberglass dikembangkan melalui proses filament berkelanjutan sehingga mempunyai sifat-sifat yang memenuhi syarat untuk bahan industri, seperti kekuatannya tinggi dan sifatnya elastis sehingga mudah dibentuk.

Karakteristik bahan fiberglass [10-12]:

- Titik leleh $1713^{\circ} \mathrm{C}$

- Titik didih $2000^{\circ} \mathrm{C}$

- Kekuatan tarik $3450 \mathrm{MPa}$

- Density $2,57 \mathrm{gram} / \mathrm{cm}^{3}$

Bahan fiberglass pada umumnya terdiri dari 11 macam bahan, 6 macam sebagai bahan utama dan 5 macam sebagai bahan finishing. Sebagai bahan utama yaitu aerosil, pigmen, resin, katalis, talk, mat, sedangkan sebagai bahan finishing antara lain: aseton, PVA, mirror, cobalt, dan dempul [10-12].

\section{METODE PENELITIAN}

Rancang bangun dan pengujian dilaksanakan pada bulan Maret sampai September 2016, di laboratorium teknik konversi energi, bengkel mekanik teknik mesin Politeknik Negeri Ujung Pandang.

Adapun bahan yang digunakan adalah magnet permanen, kumparan, Besi plat (4 mm), besi siku, besi hollow, baut, mur, bantalan, propeller kipas angin bekas, elektroda, besi pejal (poros), cat, drum, isolasi, pulley, V-belt, dan Kabel NYYHY dengan spesifikasi SNI 04-2700, SPLN 42-6-2, kawat serabut, tembaga lunak, diameter kawat @0.25 mm, diameter isolasi $0.8 \mathrm{~mm}$, diameter luar 8.9-11.0 $\mathrm{mm}$, max voltage $500 \mathrm{~V}$, max current $20 \mathrm{~A}$ at $30{ }^{\circ} \mathrm{C}$. Adapun bahan utama pembuatan fibegrglass addalah resin, katalis dan mat.

\section{A. Metode Pembuatan}

Pembuatan generator kedap air ini merupakan pengembangan dari penelitian yang terdahulu. Adapun kegiatan pembuatan generator kedap air ini meliputi dua tahap utama:

a. Pembuatan bagian generator yaitu stator dan rotor;

b. Pembuatan rangka untuk pengujian.

Generator kedap air yang dibuat ini, rotor dan statornya berbentuk lempengan (piringan) yang diletakkan sejajar. Untuk lebih jelasnya dapat dilihat pada gambar dibawah ini:

\section{Pembuatan bagian generator yaitu stator dan rotor}

a. Pembuatan stator satu fasa dan tiga fasa

Pada stator diletakkan kumparan yang terdiri atas 7 buah dengan jumlah lilitan tiap kumparan yaitu 375 lilit dan perbedaan sudut sebesar $51,4^{\circ}$, seluruh kumparan dihubungkan secara seri sehingga dari 7 kumparan akan terbentuk sistem satu fasa. Sedangkan pada sistem tiga fasa terdiri atas 6 buah kumparan yang berjumlah 800 lilit tiap kumparan dengan perbedaan sudut sebesar $60^{\circ}$ dan dua buah kumparan dihubungkan secara seri. 
99 Andreas Pangkung, Marhatang, A. Muh. Raihan, Aulia Ramadhana. Rancang Bangun Generator Kedap Air Untuk PLTPH Pada Aliran Sungai

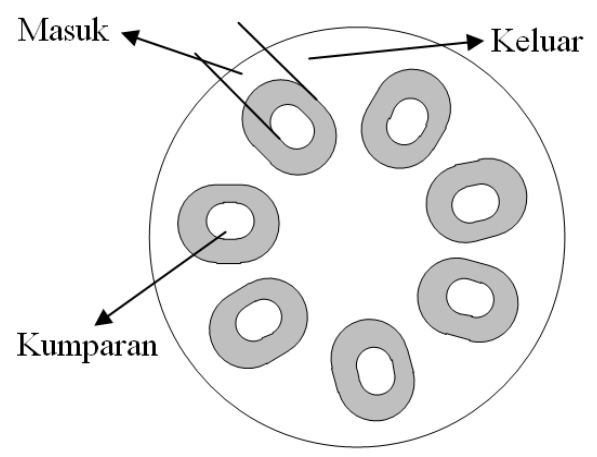

Gambar 3. Susunan kumparan pada stator dengan sistem satu fasa

Adapun langkah-langkah pembuatan stator adalah sebagai berikut:

(1) Membuat mal cetakan stator

- Menyiapkan tripleks dengan ukuran $40 \mathrm{~cm}$ x $40 \mathrm{~cm}$

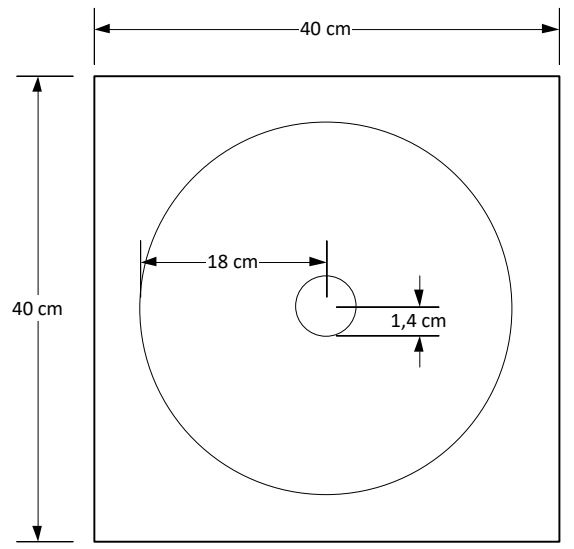

Gambar 4. Tripleks untuk alas mal cetakan stator

- Membuat dua buah lingkaran pada tripleks dengan :

- Jari-jari lingkaran luar $=18 \mathrm{~cm}$

- Jari-jari lingkaran dalam $=1,4 \mathrm{~cm}$

- Membuat garis didalam lingkaran dalam sehingga terbagi atas 7 ruang dengan perbedaan sudut $51^{\circ}$ untuk sistem satu fasa, tampak seperti gambar berikut ini:

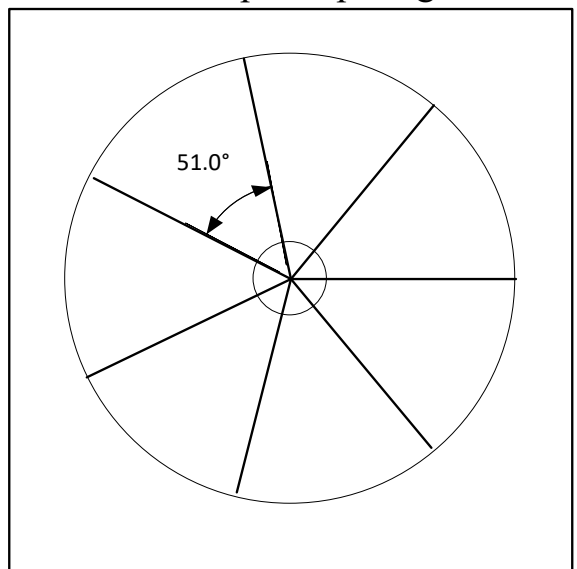

Gambar 5. Alas cetakan stator diberikan garis dengan perbedaan sudut $51^{\circ}$ 
Sedangkan untuk sistem tiga fasa kita membuat garis didalam lingkaran dalam terbagi atas 6 ruang dengan perbedaan sudut $60^{\circ}$.

- Diantara lingkaran dalam dan lingkaran luar akan terbentuk tujuh bagian/ruang. Bagianbagian tersebut $(1,2,3,4,5,6$ dan 7) merupakan tempat meletakkan kumparan stator sistem satu fasa seperti pada gambar berikut ini:

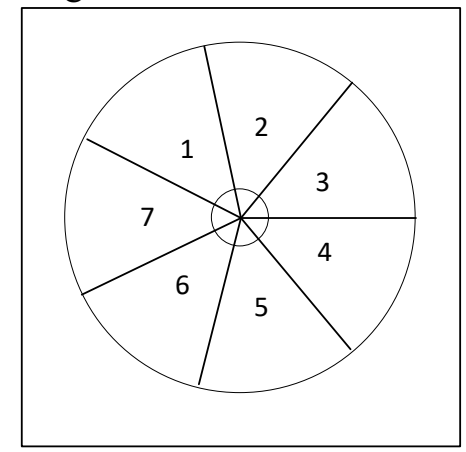

Gambar 6. Alas mal cetakan stator yang terbagi tujuh bagian

Untuk sistem tiga fasa akan terbentuk enam bagian/ruang yang merupakan tempat meletakkan kumparan stator;

- Menyiapkan tripleks dengan ukuran $40 \mathrm{~cm}$ x $40 \mathrm{~cm}$ dan ketebalan $40 \mathrm{~mm}$. untuk dinding bagian luar mal pencetakan stator.

- Membuat lingkaran dengan jari-jari $18 \mathrm{~cm}$, seperti gambar berikut ini:

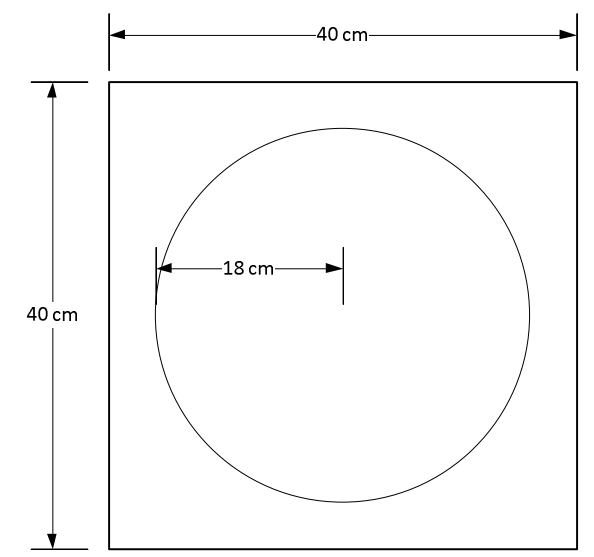

Gambar 7. Tripleks dengan ketebalan $40 \mathrm{~cm}$

- Memotong lingkaran bagian dalam tersebut sehingga terbentuk mal untuk mencetak stator seperti gambar berikut ini:

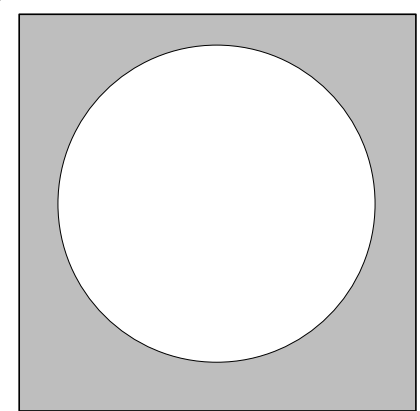

Gambar 8. Dinding bagian luar mal cetakan stator 
101 Andreas Pangkung, Marhatang, A. Muh. Raihan, Aulia Ramadhana. Rancang Bangun Generator Kedap Air Untuk PLTPH Pada Aliran Sungai

- Membuat tripleks berbentuk lingkaran dengan jari-jari 1,4 cm juga dengan ketebalan $4 \mathrm{~cm}$ untuk bagian dalam mal pencetakan stator, seperti gambar berikut ini:

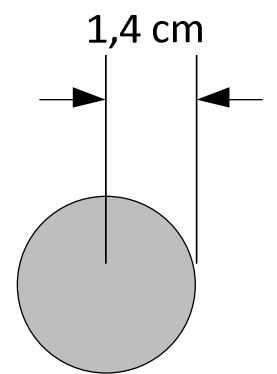

Gambar 9. Dinding bagian dalam mal cetakan stator

- Menempelkan dinding luar dan dalam tepat ditengah alas cetakan stator;

- Meletakkan kumparan stator di bagian/ruang tersebut.

(2) Pencetakan stator

- Menyiapkan mal cetakan stator, lalu menggunting kain serat fiber (mat) sesuai ukuran mal;

- Mengoleskan mirror/pelicin pada mal cetakan;

- Membuat campuran fiberglass dengan cara sebagai berikut:

- Menyiapkan wadah sebagai tempat adonan fiberglass berupa kaleng bekas atau mangkuk yang bersih.

- Resin sejumlah 5000 gram dicampur dengan katalis 125 gram (perbandingan 40:1) dan diaduk rata. Pemberian katalis dilakukan bertahap, banyak sedikitnya katalis akan mempengaruhi cepat atau lambatnya proses pengeringan. Pada cuaca yang dingin akan dibutuhkan katalis yang lebih banyak.

- Campuran fiberglass siap untuk dipakai.

- Memasang serat fiber kemudian menuang cairan fiberglass sebagai dasar cetakan;

- Meletakkan kumparan stator dengan susunan yang telah diatur sebelumnya, dan ujung kumparan disambungkan dengan kabel lalu ditarik keluar. Kemudian menuangkan kembali cairan fiberglass sehingga semua kumparan dan kabel tertutupi oleh cairan fiberglass;

- Cetakan dibiarkan beberapa jam hingga kering;

- Melepaskan stator dari cetakan.

b. Pembuatan rotor

Rotor yang dipakai dalam generator ini merupakan rotor yang dipakai pada penelitian yang terdahulu. Rotor merupakan bagian generator yang bergerak/berputar. Pada rotor terdapat magnet berupa magnet permanen. Pada rotor ini dipasang delapan buah magnet secara selang-seling dengan perbedaan sudut $45^{\circ}$. Adapun langkah pembuatan rotor adalah sebagai berikut:

(1) Pembuatan pola peletakan magnet

- Menyiapkan patron berukuran $40 \mathrm{~cm}$ x $40 \mathrm{~cm}$ untuk membuat pola penempatan magnet pada rotor;

- Membuat dua buah lingkaran dengan jari-jari masing $12 \mathrm{~cm}$ dan $18 \mathrm{~cm}$;

- Memotong patron yang berada di luar lingkaran;

- Membuat garis diameter sebanyak 4 buah yang memotong lingkaran dalam dan lingkaran luar dengan perbedaan sudut $45^{\circ}$ sehingga membentuk 8 bagian;

- Membuat garis singgung pada lingkaran dalam yang memotong garis diameter; 
- Membuat dua garis sejajar pada masing-masing ujung garis singgung tersebut ke lingkaran luar;

- Membuat langkah 4 diatas untuk semua garis singgung;

- Membuat arsiran seperti gambar dibawah. Bagian yang diarsir tersebut merupakan tempat posisi magnet yang akan dipasang pada plat;

- Keluarkan bahagian yang diarsir, sehingga terbentuk pola untuk penempatan magnet pada rotor.

(2) Pembuatan piringan rotor

- Memotong dua plat logam dengan ketebalan 4 berbentuk lingkaran dengan diameter luar 36 $\mathrm{cm}$ dan diameter dalam $4 \mathrm{~cm}$;

- Membuat lingkaran dalam dengan diameter $4 \mathrm{~cm}$ dan 4 buah lubang kecil dengan diameter $10 \mathrm{~mm}$ pada kedua plat baja tersebut;

- Meletakkan patron pada plat;

- Meletakkan magnet pada tempatnya satu persatu sesuai pola patron yang telah dibuat;

- Bila semua magnet telah diletakkan pada tempatnya, cabut patronnya.

(3) Pencetakan rotor

- Membuat cetakan rotor seperti cetakan stator diatas sesuai dengan ukuran plat;

- Membuat campuran larutan fiberglass untuk rotor seperti pada tahap pencetakan stator diatas;

- Mengoleskan mirror/bahan pelicin pada mal cetakan rotor;

- Menuang fiberglass ke cetakan sebagai dasar untuk meletakkan plat rotor;

- Meletakkan plat rotor ke dasar cetakan;

- Menuang cairan fiberglass pada mal cetakan hingga menutupi magnet;

- Cetakan dibiarkan beberapa jam hingga kering;

- Melepaskan rotor dari cetakan.

\section{Pembuatan rangka untuk pengujian}

Rangka untuk pengujian generator kedap air ini terbuat dari drum yang nantinya akan diisi air pada saat pengujian. Berikut langkah-langkah pembuatan rangka :

- Siapkan besi siku dan besi hollow secukupnya;

- Siapkan satu buah drum;

- Potong besi siku dengan ukuran sebagai berikut:

- Ukuran $88 \mathrm{~cm}: 2$ buah

- Ukuran $55 \mathrm{~cm}: 2$ buah

- Ukuran $35 \mathrm{~cm}: 3$ buah

- Ukuran 13,5 cm : 3 buah

- Sambungkan besi siku tersebut pada drum sebagai dudukan untuk motor dengan menggunakan mesin las;

- Potong besi hollow dengan ukuran $58 \mathrm{~cm}$ sebanyak 4 buah;

- Sambungkan besi hollow tersebut di dalam drum sebagai rangka untuk stator dan rotor dengan menggunakan mesin las.

\section{B. Metode Pengujian}

Pengujian terhadap generator kedap air ini dilakukan dengan tujuan untuk mengetahui karakteristik dari generator. Sebelum melakukan pengujian generator, terlebih dahulu menghubungkan 2 kumparan secara seri, sehingga dari 6 kumparan yang terdapat pada stator terbentuk sistem tiga fasa. 
103 Andreas Pangkung, Marhatang, A. Muh. Raihan, Aulia Ramadhana. Rancang Bangun Generator Kedap Air Untuk PLTPH Pada Aliran Sungai

Adapun penyambungannya yaitu 1b-4a, 2b-5a, dan 3b-6a. kawat dengan kode 1a,2a, dan 3a merupakan masukan, sedangkan 4b, 5b, dan 6b merupakan keluaran. (Multazam dkk, 2010).

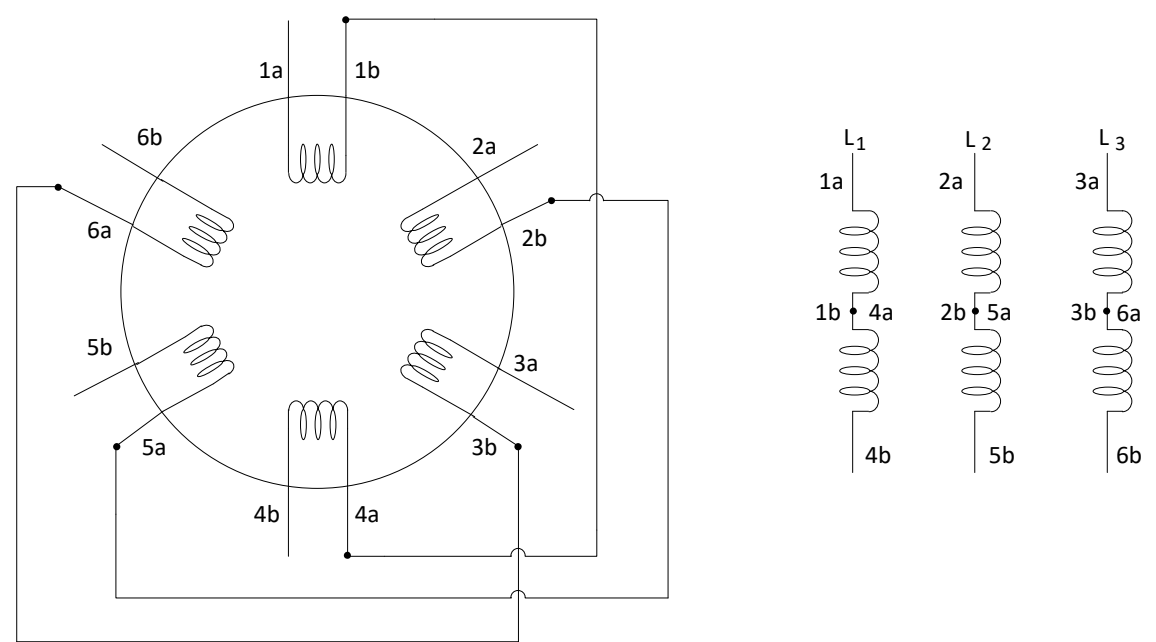

Gambar 10. Dua kumparan pada stator dihubung seri

Secara garis besar pengujian generator kedap air terbagi atas 4 yaitu:

1. Pengujian generator kedap air tanpa beban

Pengujian generator tanpa beban untuk mengetahui perbandingan tegangan keluaran dari generator dengan melakukan berbagai macam pengujian, yaitu sebagai berikut:

a. Membandingkan 2 macam stator dengan jumlah fasa yang berbeda yaitu satu fasa dan tiga fasa.

b. Membandingkan antara hubungan $\mathrm{Y}$ dan hubungan $\Delta$ pada sistem tiga fasa generator.

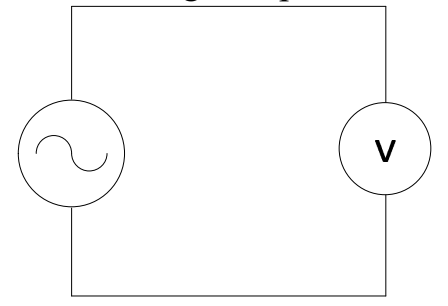

Gambar 11 Rangkaian pengujian generator satu fasa tanpa beban

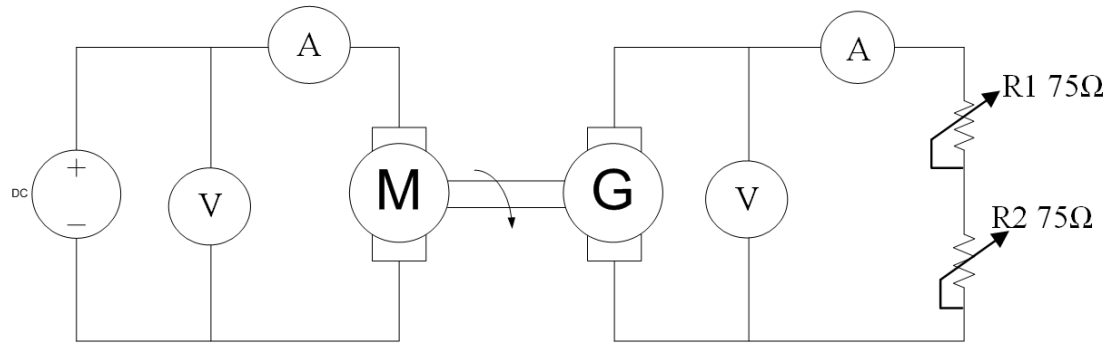

Gambar 12. Rangkaian pengujian generator kedap air, berbeban dengan penggerak motor. 


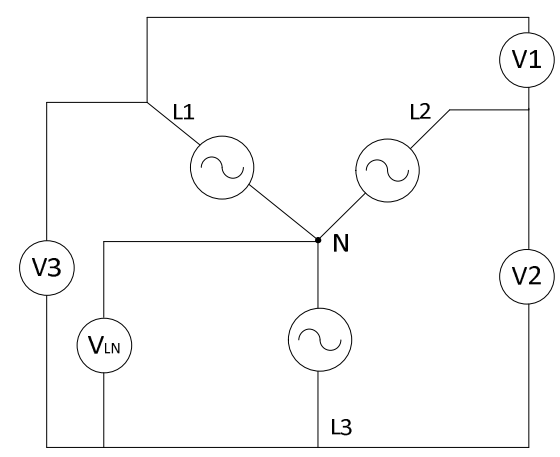

Gambar 13. Rangkaian pengujian generator tiga fasa tanpa beban untuk hubungan $\mathrm{Y}$

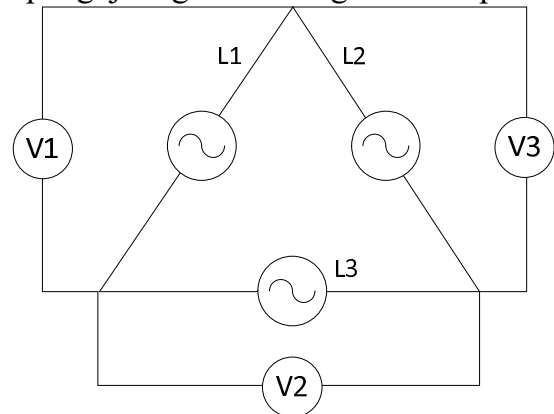

Gambar 14. Rangkaian pengujian generator tiga fasa tanpa beban untuk hubungan $\Delta$

2. Pengujian generator kedap air berbeban

Setelah melakukan pengujian tanpa beban, dapat diketahui tegangan maksimal dengan putaran rendah. Pengujian generator berbeban yaitu dengan mengisi baterai (aki).

\section{HASIL DAN PEMBAHASAN}

\section{A. Tabel Hasil Pengujian}

Tabel 1. Data pengujian satu fasa dengan penggerak turbin, berbeban.

\begin{tabular}{|c|c|c|c|c|c|c|}
\hline No. & $\begin{array}{c}\mathbf{N} \\
(\mathbf{r p m})\end{array}$ & $\begin{array}{c}\mathbf{V}_{\mathbf{g}} \\
(\mathbf{V o l t})\end{array}$ & $\begin{array}{c}\mathbf{V}_{\mathbf{b}} \\
(\mathbf{V o l t})\end{array}$ & $\begin{array}{c}\mathbf{I}_{\mathbf{b}} \\
(\mathbf{A})\end{array}$ & $\begin{array}{c}\mathbf{V}_{\text {air }} \\
(\mathbf{m} / \mathbf{s})\end{array}$ & $\begin{array}{c}\text { Celah udara } \\
(\mathbf{m m})\end{array}$ \\
\hline 1 & 108 & 11 & 12 & 0,02 & 0,58 & 2 \\
\hline
\end{tabular}

Tabel 2. Data pengujian tiga fasa dengan turbin, tanpa beban, hubungan $\mathrm{Y}$

\begin{tabular}{|c|c|c|c|c|c|c|c|}
\hline No. & $\begin{array}{c}\mathbf{N} \\
(\mathbf{r p m})\end{array}$ & $\begin{array}{c}\mathbf{V}_{\text {L1-L2 }} \\
(\mathbf{V o l t})\end{array}$ & $\begin{array}{c}\mathbf{V}_{\text {L1-L3 }} \\
(\mathbf{V o l t})\end{array}$ & $\begin{array}{c}\mathbf{V}_{\mathbf{L 2}-L 3} \\
(\mathbf{V o l t})\end{array}$ & $\begin{array}{c}\mathbf{V}_{\mathbf{L}-\mathbf{N}} \\
(\mathbf{V o l t})\end{array}$ & $\begin{array}{c}\mathbf{V}_{\text {air }} \\
(\mathbf{m} / \mathbf{s})\end{array}$ & $\begin{array}{c}\text { Celah udara } \\
(\mathbf{m m})\end{array}$ \\
\hline 1 & 108 & 28 & 30 & 28 & 17 & 0,58 & 2 \\
\hline
\end{tabular}

Tabel 3. Data pengujian tiga fasa dengan penggerak turbin, tanpa beban, hubungan $\Delta$

\begin{tabular}{|c|c|c|c|c|c|c|}
\hline No. & $\begin{array}{c}\mathbf{N} \\
(\mathbf{r p m})\end{array}$ & $\begin{array}{c}\mathbf{V}_{\text {L1-L2 }} \\
(\mathbf{V o l t})\end{array}$ & $\begin{array}{c}\mathbf{V}_{\text {L1-L3 }} \\
(\mathbf{V o l t})\end{array}$ & $\begin{array}{c}\mathbf{V}_{\mathbf{L} 2-\mathrm{L3}} \\
\mathbf{( V o l t )}\end{array}$ & $\begin{array}{c}\text { Vair } \\
(\mathbf{m} / \mathbf{s})\end{array}$ & $\begin{array}{c}\text { Celah udara } \\
(\mathbf{m m})\end{array}$ \\
\hline 1 & 108 & 11 & 10 & 12 & 0,58 & 2 \\
\hline
\end{tabular}

Tabel 4. Data kecepatan aliran sungai.

\begin{tabular}{|c|c|c|c|c|c|c|c|c|}
\hline No. & $\begin{array}{c}\text { Jarak } \\
\text { (m) }\end{array}$ & $\begin{array}{c}\text { Waktu } \\
\text { (s) }\end{array}$ & No. & $\begin{array}{c}\text { Jarak } \\
\text { (m) }\end{array}$ & $\begin{array}{c}\text { Waktu } \\
\text { (s) }\end{array}$ & No. & $\begin{array}{c}\text { Jarak } \\
\text { (m) }\end{array}$ & $\begin{array}{c}\text { Waktu } \\
\text { (s) }\end{array}$ \\
\hline 1 & 2 & 3,8 & 5 & 2 & 3,69 & 9 & 2 & 3,08 \\
\hline 2 & 2 & 3,34 & 6 & 2 & 3,55 & 10 & 2 & 3,48 \\
\hline 3 & 2 & 3,69 & 7 & 2 & 3,22 & Rata-rata & 2 & $\mathbf{3 , 4 4 3}$ \\
\hline 4 & 2 & 3,1 & 8 & 2 & 3,48 & \multicolumn{2}{|c|}{ Kec. Aliran Air } & 0,58088876 \\
\hline
\end{tabular}


105 Andreas Pangkung, Marhatang, A. Muh. Raihan, Aulia Ramadhana. Rancang Bangun Generator Kedap Air Untuk PLTPH Pada Aliran Sungai

\section{B. Pembahasan}

\section{Generator ac Satu Fasa Kedap Air dengan Penggerak Motor, Tanpa Beban dan Tanpa Pencelupan}

Pada pengujian generator tanpa beban, jumlah belitan pada stator sangat mempengaruhi tegangan keluaran generator, semakin banyak belitan maka semakin besar pula tegangan keluaran generator. Pada pengujian laboratorium dengan putaran $1306 \mathrm{rpm}$, celah udara sebesar $2 \mathrm{~mm}$ maka tegangan keluaran generator sebesar 165 volt.

Dari gambar 15, bisa disimpulkan bahwa putaran sangat mempengaruhi tegangan keluaran generator, makin besar putaran maka makin besarpula tegangan keluarannya.

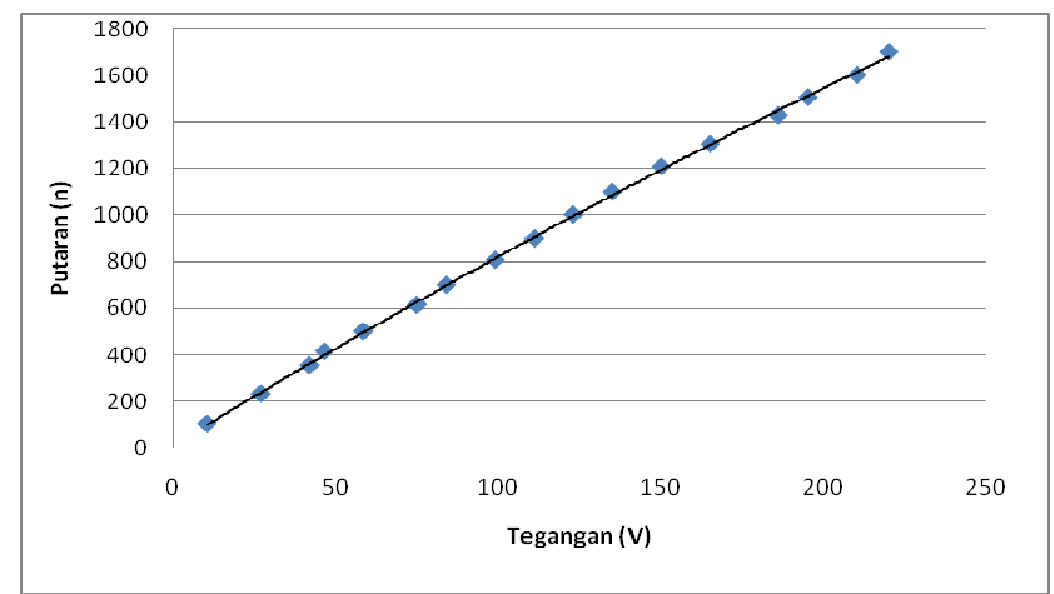

Gambar 15. Putaran sebagai fungsi tegangan pada generator satu fasa tanpa beban dan tanpa pencelupan.

\section{Generator ac satu fasa kedap air dengan penggerak motor, berbeban dan tanpa pencelupan}

Pada pengujian berbeban, pembebanan pada generator mempengaruhi putaran dan tegangan keluaran generator. Semakin besar beban yang diberikan pada generator maka putaran akan semakin melambat. Pada pengujian laboratorium dengan menggunkan beban sebesar $89 \mathrm{ohm}$, celah udara sebesar $2 \mathrm{~mm}$, putaran $1302 \mathrm{rpm}$ maka tegangan keluaran yang dihasilkan sebesar 130 volt dan arus sebesar 1,9 amper.

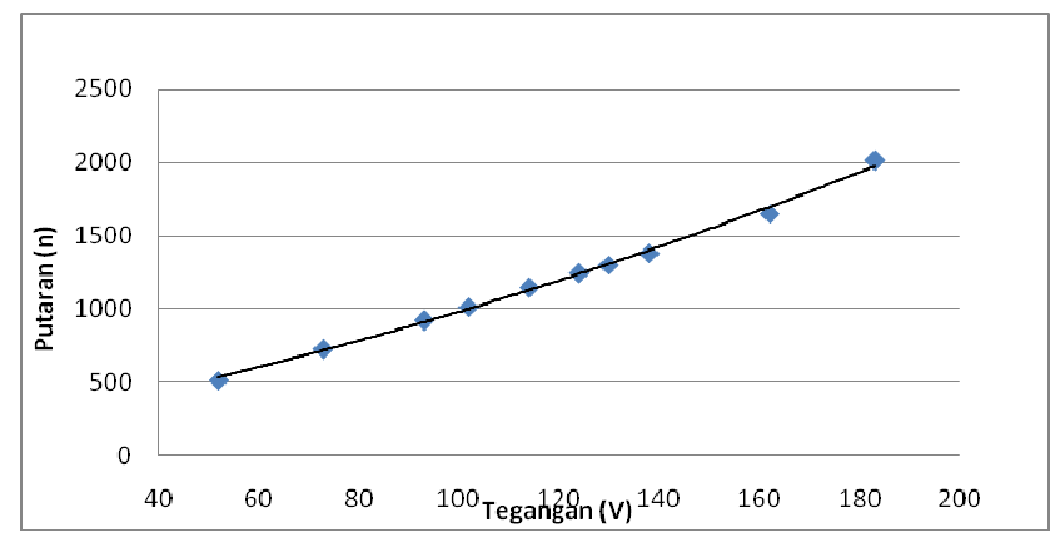

Gambar 16. Putaran sebagai fungsi tegangan pada generator satu fasa, berbeban dan tanpa pencelupan. 


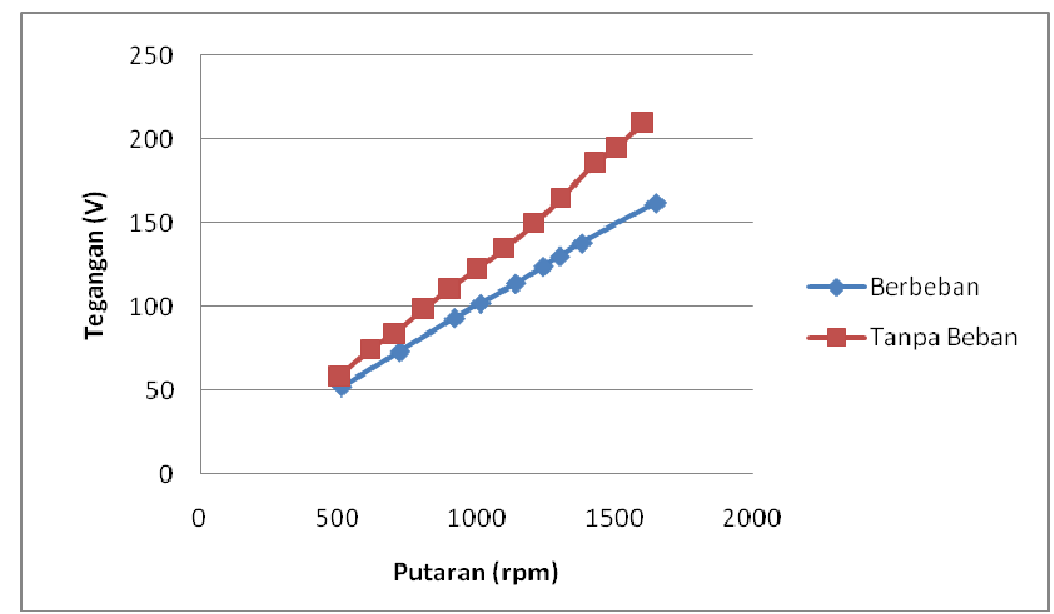

Gambar 17. Perbandingan antara data berbeban dengan tanpa beban tanpa pencelupan

\section{Generator ac satu fasa kedap air tanpa beban, tercelup}

Pada pengujian kekedapan air ini tentunya harus mempertimbangkan faktor keselamatan. Oleh karena itu dibutuhkan pengukuran tahanan isolasi antara generator dengan bodi, pada saat pengukuran tahanan isolasi didapatkan tahanan sebesar $50.000 \mathrm{ohm}$, dari segi teori untuk faktor keamaan tegangan kerja harus 1000 kali tahanan isolasi, artinya jika tahanan sebesar $50.000 \mathrm{ohm}$ maka tegangan kerjanya hanya bisa sebesar 50 volt.

Dari hasil pengujian laboratorium untuk mendapatkan tegangan 50 volt dibutuhkan putaran sebesar $404 \mathrm{rpm}$.

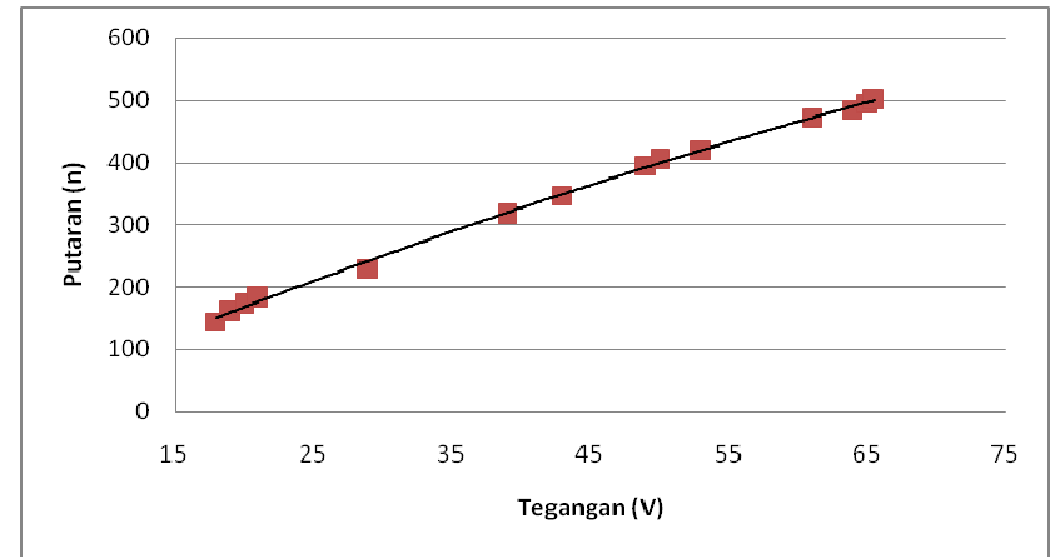

Gambar 18. Putaran sebagai fungsi tegangan pada generator satu fasa tanpa beban dan tercelup.

\section{Generator ac Satu Fasa Kedap Air Berbeban, Tercelup}

Pada pengujian lapangan banyak faktor yang mempengaruhi untuk mendapatkan tegangan keluaran yang diinginkan, salah satunya adalah putaran, putaran yang didapatkan dilapangan berdasarkan kecepatan aliran air yang bisa dimanfaatkan oleh turbin. Pada saat pengujian kecepatan air sebesar $0,58 \mathrm{~m} / \mathrm{s}$ sehingga putaran yang didapatkan hanya sebesar $108 \mathrm{rpm}$, dengan putaran sebesar $108 \mathrm{rpm}$ hanya bisa menghasilkan tegangan keluaran sebesar 11 volt. Dengan tegangan sebesar 11 volt kita bisa melakukan pembebanan dengan cara mengisi aki, tentunya hal itu membutuhkan perangkat tambhan yang merubah tegangan ac yang sebesar 11 volt menjadi tegangan dc 12 volt untuk mengisi aki. 
107 Andreas Pangkung, Marhatang, A. Muh. Raihan, Aulia Ramadhana. Rancang Bangun Generator Kedap Air Untuk PLTPH Pada Aliran Sungai

\section{KESIMPULAN}

Setelah membuat generator $a c$ kedap air untuk PLTPH dapat ditarik kesimpulan sebagai berikut:

1. Generator kedap air dapat menghasilkan tegangan walaupun kecepatan air sungai rendah. Sistem satu fasa menggunakan belitan stator sebanyak 375 lilitan, dan celah $2 \mathrm{~mm}$ pada putaran $108 \mathrm{rpm}$ dapat menghasilkan tegangan 11 Volt. Pada sistem tiga fasa menggunakan belitan stator sebanyak 800 lilitan, dan celah $2 \mathrm{~mm}$ pada putaran $108 \mathrm{rpm}$ dengan hubungan $\mathrm{Y}$ line to line dapat menghasilkan tegangan 28 Volt dan line to netral menghasilkan tegangan 17 Volt, sedangkan dengan hubungan $\Delta$ dapat menghasilkan tegangan 11 Volt. Sehingga dapat mengisi baterai (aki) dengan syarat menambahkan komponen penyearah. Generator kedap air memiliki tahanan isolasi sebesar $50 \mathrm{~K} \Omega$, maka tegangan kerjanya sebesar $50 \mathrm{~V}$.

2. Rancang Bangun Generator Kedap Air Untuk PLTPH Pada Aliran Air Sungai hasil perancangan kami dapat mengisi sebuah baterai dan memakai inverter untuk menerangi 1 unit rumah serta dapat digunakan di daerah yang memiliki potensi aliran air sungai yang belum terjangkau aliran listrik PLN karena memiliki banyak kaunggulan, salah satunya yaitu konstruksinya yang sederhana.

\section{DAFTAR PUSTAKA}

[1] Daniel, Rente dan Fidelis. "Rancang Bangun Pembangkit Listrik Tenga Picohydro Tipe Propeller Menggunakan Aliran Air Sungai”. Makassar: Politeknik Negeri Ujung Pandang, 2015.

[2] Rossouw, G. F. "Analysis and Design of Axial Fluks Permanent Magnet Wind Generator System for Direct Battery Charging Aplications", thesis. Afrika Selatan: Departement of Electrical and Electronic Engineering Stellenbosch University, 2009.

[3] Sofian, E. "Studi Bentuk Rotor Magnet pada Generator Sinkron Magnet Permanen Fluks Axial Tanpa Inti Stator", Skripsi, Depok: Program Studi Teknik Elektro, Universitas Indonesia, 2011.

[4] Jara Werner, et al. "Axial Flux PM Machine for Low Wind Power Generation”. XIX International Conference on Electrical Machines, 2010.

[5] F. Jacek Gieras, Rong-Jie Wang, Maarten J. Kamper. "Axial Flux Permanent Magnet Brushkess Machine”. New York: Kluwer Academic Publisher, 2004.

[6] Jackt Fritz. "Small and Mini Hydropower System". New York: Mc. Graw-Hill Book Company, 1984.

[7] Dadenkar, M.M dan Sharman K.N. "Pembangkit Listrik Tenaga Air". Jakarta: UI Press, 1991.

[8] Riyadi Sugeng. “Turbin Air”. Malang: Universitas Negeri Malang, 2012.

[9] Selatan, E. Sulawesi. "Potensi Energi Terbarukan dan Pemanfaatan di Sulawesi Selatan". 2014.

[10] Gunandi. "Teknik Bodi Otomotif Jilid 3". Direktorat Pembinaan Sekolah Menengah KejuruanDirektorat Jenderal Manajemen Pendidikan Dasar dan Menengah Departemen Pendidikan Nasional, 2008.

[11] Multazam, Najamuddin dkk. "Pembuatan Generator AC 3 Fasa Fiberglass". Makassar: Politeknik Negeri Ujung Pandang, 2010.

[12] Gupta V.B, V.K Kothari. "Manufactured Fibre Technology". London: Chapman and Hall, 1997. 